Shock. 2016 April ; 45(4): 393-403. doi:10.1097/SHK.0000000000000520.

\title{
A PPAR $\gamma$ agonist enhances bacterial clearance through neutrophil extracellular trap formation and improves survival in sepsis
}

\author{
Cláudia V. Araújo ${ }^{1,2}$, Clarissa Campbell ${ }^{1}$, Cassiano F. Gonçalves-de-Albuquerque ${ }^{1}$, \\ Raphael Molinaro ${ }^{1}$, Mark J. Cody ${ }^{3,4}$, Christian C. Yost ${ }^{3,4}$, Patricia T. Bozza ${ }^{1}$, Guy A. \\ Zimmerman $^{2,4}$, Andrew S. Weyrich ${ }^{2,4}$, Hugo C. Castro-Faria-Neto ${ }^{1}$, and Adriana R. Silva ${ }^{1}$ \\ Adriana R. Silva: arsilva71@gmail.com \\ ${ }^{1}$ Laboratório de Imunofarmacologia, Instituto Oswaldo Cruz, Fundação Oswaldo Cruz, Rio de \\ Janeiro, RJ, Brazil, Av. Brasil 4365, 21040-900 \\ ${ }^{2}$ Department of Internal Medicine, University of Utah School of Medicine, Salt Lake City, Utah, \\ USA. Eccles Institute of Human Genetics, 15 North 2010 East, Bldg. 533, Rm 4220, 84112 \\ ${ }^{3}$ Department of Pediatrics University of Utah School of Medicine, Salt Lake City, Utah, USA. \\ Eccles Institute of Human Genetics, 15 North 2010 East, Bldg. 533, Rm 4220, 84112 \\ ${ }^{4}$ Program in Molecular Medicine, University of Utah School of Medicine, Salt Lake City, Utah, \\ USA. Eccles Institute of Human Genetics, 15 North 2010 East, Bldg. 533, Rm 4220, 84112
}

\section{Abstract}

Dysregulation of the inflammatory response against infection contributes to mortality in sepsis. Inflammation provides critical host defense, but it can cause tissue damage, multiple organ failure and death. Because the nuclear transcription factor peroxisome proliferator-activated receptor $\gamma$ $(\operatorname{PPAR} \gamma)$ exhibits therapeutic potential, we characterized the role of PPAR $\gamma$ in sepsis. We analyzed severity of clinical signs, survival rates, cytokine production, leukocyte influx, and bacterial clearance in a cecal ligation and puncture (CLP) model of sepsis in Swiss mice. The PPAR $\gamma$ agonist rosiglitazone treatment improved clinical status and mortality, while increasing IL-10 production and decreasing TNF- $\alpha$ and IL-6 levels, and peritoneal neutrophil accumulation $24 \mathrm{~h}$ after CLP. We noted increased bacterial killing in rosiglitazone treated mice, correlated with increased generation of reactive oxygen species. Polymorphonuclear leukocytes (PMN) incubated with LPS or E. coli and rosiglitazone increased peritoneal neutrophil extracellular trap (NET)mediated bacterial killing, an effect reversed by the PPAR $\gamma$ antagonist (GW 9662) treatment. Rosiglitazone also enhanced the release of histones by PMN, a surrogate marker of NET formation, effect abolished by GW 9662. Rosiglitazone modulated the inflammatory response and increased bacterial clearance through PPAR $\gamma$ activation and NET formation, combining immunomodulatory and host-dependent anti-bacterial effects and, therefore, warrants further study as a potential therapeutic agent in sepsis. 


\section{Keywords}

Inflammation; infection; sepsis; PPAR; neutrophil extracellular trap; bacterial elimination; bacterial clearance

\section{Introduction}

Sepsis is a frequent complication of critically ill patients causing morbidity and mortality worldwide. Clinical and preclinical studies indicate that imbalance in inflammatory mediator production has severe consequences for the host and is probably responsible for a larger proportion of death than the invading organism itself (1).

Polymorphonuclear leukocytes (PMN) represent the first line of innate immune defense against extracellular microorganisms. Classically, neutrophils are known to eliminate bacteria by phagocytic uptake and intracellular killing (2). More recently, an additional pathogen elimination mechanism was reported for neutrophils, as these cells are able to form neutrophil extracellular traps (NET) upon proper activation (3). NET are lattices of DNA, histones and granular proteins that function to trap extracellular pathogens in a process that may or may not result in neutrophil death (3). Previous studies have shown that NET are effective against different pathogens, such as Gram-negative bacteria (Salmonella typhimurium, Shigella flexneri, and E. coli) (4), gram-positive bacteria (Streptococcus pneumoniae) (5), as well as fungi (Aspegillus)(6) and protozoa (Leishmania amazonensis) (7). These structures can also be induced when neutrophils are stimulated by phorbol myristate acetate (PMA), lipopolysaccharide (LPS), interleukin-8 (IL-8), platelet-activating factor and other agonists (7). Nevertheless, the mechanisms by which these structures are formed remain incompletely defined. Some studies report intracellular signaling proteins involved in NET formation, as protein kinase C, Rac 2 (8), and mTOR regulating NET formation through HIF-1 protein expression leading to bacterial clearance (9).

Several groups have demonstrated that pharmacological activation of peroxisome proliferator-activated receptor gamma (PPAR $\gamma$ ) by natural or synthetic ligands, including thiazolidinediones (TZD), leads to anti-inflammatory effects. There are three known PPAR receptors: $\alpha, \beta / \delta$, and $\gamma$ which are all broadly involved in the regulation of various metabolic processes, especially those related to lipid and glucose homeostasis (10). PPAR $\gamma$ inhibits activity of the transcription factor NF- $\mathrm{kB}$, thereby inhibiting the expression of inflammatory cytokines such as tumor necrosis factor alpha (TNF-a) and interleukin 12 (IL-12), the expression of adhesion molecules (11). Treatment with rosiglitazone, a PPAR $\gamma$ synthetic agonist, inhibits LPS-induced lung injury as well as neutrophil infiltration in the lung and intestine, resulting in increased survival in experimental endotoxic shock (12). In addition, Standage et al. (13) showed that PPAR expression is downregulated in patients with septic shock, and the magnitude of that decrement correlates with the severity of the disease. We showed that rosiglitazone treatment protected against cerebral microvascular dysfunction, decreased leukocyte-endothelial cell interactions, and increased functional capillary density in septic animals (14). Here we asked whether the PPAR $\gamma$ receptor plays a role in modulating inflammation and bacterial killing after induction of sepsis by cecal ligation and 
puncture, a pre-clinical model of polymicrobial peritoneal infection and what mechanism would be involved in bacterial clearance.

\section{Materials and Methods}

\section{Experimental Animals}

Ten week old Male Swiss mice (Oswaldo Cruz Foundation breeding unit) weighing 25 to 30 $\mathrm{g}$ were used. The animals were kept at a constant temperature $\left(25^{\circ} \mathrm{C}\right)$ with unlimited access to pellet diet and water in a room with a $12 \mathrm{~h}$ light/dark cycle.

Animals used in our experiments died with euthanasia for peritoneal lavage procedure and without euthanasia due to sepsis complications because it was one aim of the study. We euthanized animals prior to the end of our experiment with a letal dose of ketamine and xylazin, following the Guidelines of Our Institution Animal Ethics Committee to analyze inflammatory parameters. We avoided any animal suffering and distress using anesthesia with ketamine and xylazin during surgical procedure, and all efforts were made to minimize suffering. We described the possibility of animal death without euthanasia in our study protocol submitted to our Institutional Animal Ethics Committee. Our ethics committee specifically reviewed and approved the mortality aspects of the protocol. This study was carried out in strict accordance with the recommendations in the Guide for the Care and Use of Laboratory Animals of the Animal Welfare Committee of the Oswaldo Cruz Foundation.

\section{Ethics Statement}

The Animal Welfare Committee of the Oswaldo Cruz Foundation under license number 0260-05 (CEUA/FIOCRUZ) approved the experiments in these studies. The same institution provided ethical approval created the guidelines followed by this Committee.

\section{Surgical procedure and CLP model}

Sepsis was induced by cecum ligation and puncture (CLP) as previously described $(15,16)$. After surgery, the animals received subcutaneous sterile isotonic saline $(1 \mathrm{~mL})$ for fluid resuscitation. Fifteen minutes after the CLP procedure, the mice were randomly divided into 2 groups: CLP + vehicle (DMSO, v/v, i.v.), CLP + rosiglitazone ( $0.5 \mathrm{mg} / \mathrm{kg}$, i.v.). Two additional sham-operated groups, sham + vehicle (DMSO, v/v, i.v.), sham + rosiglitazone $(0.5 \mathrm{mg} / \mathrm{kg}$, i.v. $)$, were also included in our analysis. In some experiments we also treated CLP or CLP + rosiglitazone animals with DNase $(5 \mathrm{mg} / \mathrm{kg}$ dissolved in saline solution enriched with $2 \mathrm{mM} \mathrm{CaCl}$, i.p., $1 \mathrm{~h}$ after CLP). The animals were followed for 7 days after the surgical procedure for determination of survival. Randomly selected animals were euthanized at 3 or $24 \mathrm{~h}$ after CLP for sampling of blood and biological fluids.

\section{Assessment of the severity of sepsis}

At $24 \mathrm{~h}$ after CLP, mice were scored for severity of sepsis. In this assessment, higher scores reflect increased severity. Mice were scored based on the following variables: piloerection, curved trunk, alterations in gait, seizures, lethargy, respiratory rate, lacrimation, grip strength, feces alterations, body tone, and body temperature alterations (adapted from (17) and (14)). Each animal received a total score between 1 and 11 and was ranked as: 1-3 (mild 
sepsis); 3-7 (moderate sepsis) and 8-11 (severe sepsis). In our experimental conditions, most animals were ranked as moderate sepsis.

\section{Leukocyte analysis}

Twenty-hours after CLP, the mice were anaesthetized with isoflurane, and blood samples were collected by cardiac puncture in tubes containing $100 \mu \mathrm{L}$ of $3.2 \%$ sodium citrate. They were euthanized immediately after the procedure in a carbon dioxide $\left(\mathrm{CO}_{2}\right)$ chamber. Peritoneal lavage was performed with $3 \mathrm{~mL}$ of phosphate-buffered saline (PBS) solution. Total leukocyte counts were performed in Neubauer chambers using optical microscopy, after diluting the samples (40x) in Turk solution (2\% acetic acid). Differential leukocyte analysis was performed on cytospin smears stained by panotic solution.

\section{Measurement of oxidative stress}

Blood cells obtained from vehicle-treated or rosiglitazone-treated septic mice were incubated with dihydrorhodamine 123 (DHR) for $15 \mathrm{~min}$ at $37^{\circ} \mathrm{C}$ and with phorbol myristate acetate (PMA) for $15 \mathrm{~min}$ at $37^{\circ} \mathrm{C}$ in the absence or presence of catalase for measurement of hydrogen peroxide activity after $15 \mathrm{~min}$. In one set of experiments, blood cells from untreated septic mice were obtained and incubated in vitro with rosiglitazone (5 $\mu \mathrm{M})$ for $1 \mathrm{~h}$ before DHR incubation. Erythrocyte lysis was performed with ammoniumchloride-potassium (ACK) lysis buffer. The blood was centrifuged and the supernatant discarded. The cells were washed twice to remove the excess fluorescence and resuspended in buffer solution (PBS). All samples were analyzed by flow cytometry on the FACScalibur ${ }^{\circledR}$ and the data were analyzed with the FCS Express 3.0 software.

\section{Cytokine measurement}

Levels of TNF-a, Interleukin 6 (IL-6) and Interleukin 10 (IL-10) from the peritoneal fluid were measured by enzyme-linked immunosorbent assay (ELISA) using a commercial kit according to the manufacturer's instructions (Duoset kit - R\&D Systems). The plates were read at $450 \mathrm{~nm}$, and the cytokine concentrations were estimated by plotting against a standard curve constructed with the recombinant cytokines.

\section{Determination of CFU}

The number of colony-forming units (CFU) in the peritoneal lavage was determined 3 or 24 $\mathrm{h}$ after CLP diluting the samples 10 or 100 times, seeding on culture plates and incubating under aerobic and sterile conditions on LB-agar for $24 \mathrm{~h}$ at $37^{\circ} \mathrm{C}$. The number of bacteria colonies were counted and expressed as $\mathrm{CFU} / \mathrm{mL}$.

\section{DNA measurement}

NET formation was quantified in the free cell peritoneal lavage fluid by using the Picogreen dsDNA kit (Invitrogen) according to the manufacturer's instructions.

\section{Live cell imaging from septic mice}

The live cell imaging and/or scanning electron microscopy were performed as described by Yost CC et al., 2009 (18) with some changes. Animals were submitted to CLP and 15 min 
after the procedure treated with rosiglitazone $(0.5 \mathrm{mg} / \mathrm{kg}$, i.v. $)$. The sham-operated animals received the same treatment as the control group. After 3 hours, the animals were euthanized by $\mathrm{CO} 2$ chamber and the peritoneal fluid was collected. The peritoneal fluid was placed on glass coverslips coated with poly-l-lysine 1 hour at $37^{\circ} \mathrm{C}$ in $5 \% \mathrm{CO}_{2} / 95 \%$ air. After preincubation, the cells were gently washed with PBS and incubated with a mixture of cellpermeable (Syto Green) and impermeable (Sytox Orange) DNA fluorescent dyes. Confocal microscopy and NET formation visualization was accomplished using a FV300 $1 \times 81$ microscope and FluoView software (Olympus, Center Valley, PA) maintained by the Fluorescent Microscopy Core Facility at the University of Utah. 60× objectives were used. Z-series images were obtained at a step size $0.5 \mu \mathrm{m}$ over a range of $20 \mu \mathrm{m}$ for each field. Adobe Photoshop CS2 was used for image processing (Adobe Systems, San Jose, CA).

\section{Human PMN isolation}

PMN were isolated from anticoagulated (ACD or EDTA) venous blood of healthy adults under a protocol approved by the University of Utah Institutional Review Board, and informed consent was obtained in accordance with the Declaration of Helsinki. PMN suspensions ( $>95 \%$ pure) were prepared by positive immunoselection using anti-CD15coated microbeads and an auto-MACS cell sorter (Miltenyi Biotec). The PMN were resuspended at indicated concentrations in M199 culture medium $\left(37^{\circ} \mathrm{C}\right)$.

\section{Live cell imaging}

PMN $\left(2 \times 10^{6}\right.$ cells $\left./ \mathrm{mL}\right)$ were incubated with control buffer or stimulated with LPS (0.1 $\mathrm{ng} / \mathrm{mL})$ in the presence or absence of rosiglitazone $(0.5 \mu \mathrm{M})$ and/or $\mathrm{GW} 9662(0.5 \mu \mathrm{M})$ for 1 $\mathrm{h}$ at $37^{\circ} \mathrm{C}$ in $5 \% \mathrm{CO}_{2} / 95 \%$ air on poly-L-lysine coated glass coverslips. After stimulation and/or treatment, the PMN were gently washed with PBS and incubated with a mixture of cell-permeable (Syto-Green) and impermeable (Sytox-Orange) DNA fluorescent dyes. Confocal microscopy was accomplished using a FV300 $1 \times 81$ microscope and FluoView software (Olympus, Center Valley, PA). Both 20x and 60x objectives were used. Z-series images were obtained at a step size $0.5 \mu \mathrm{m}$ over a range of $20 \mu \mathrm{m}$ for each field.

\section{Western blotting for protein histone $\mathrm{H} 3$ detection}

After live cell imaging of NET, the slides were washed with 1x PBS to remove excess fluorescent dyes, and then treated with DNAse $(2.5 \mathrm{U} / \mathrm{mL})$ for $15 \mathrm{~min}$ to degrade the extracellular nuclear material. The reaction was stopped using EDTA. After 5 min of treatment, the supernatants were removed and placed in $1.5 \mathrm{~mL}$ tube and centrifuged at 300 $\mathrm{g}$ for $2 \mathrm{~min}$ to remove contaminating whole PMN. After centrifugation, the supernatant was collected, placed in a sterile tube, prepared for western blotting using 4x Lammelli buffer and frozen at $-80^{\circ} \mathrm{C}$ for subsequent analysis of histone $\mathrm{H} 3$ content. Western blots were performed according to manufacturer's instructions (Odyssey ${ }^{\mathrm{TM}}$ system, Li-Cor, Biosciences, USA). Ten micrograms of total protein was applied in each well. After transfer, the membrane was incubated for $1 \mathrm{~h}$ with blocking solution (Odyssey ${ }^{\mathrm{TM}}$ system - Li-Cor, Biociences, USA) at $4^{\circ} \mathrm{C}$. Subsequently, the membrane was incubated overnight with a polyclonal antibody to detect human histone H3 protein (Cell Signaling Technology). The detection and quantitation of bands was performed using the Odyssey Infrared Imaging System (Li-Cor Biosciences, USA). 


\section{Bacterial killing assay}

Bacterial killing efficiency of freshly-isolated PMN was determined. PMN were incubated for $30 \mathrm{~min}$ at $37^{\circ} \mathrm{C}$ in $5 \% \mathrm{CO} 2 / 95 \%$ air alone or with the phagocytosis inhibitors cytochalasin B and D $(10 \mu \mathrm{M})$ or DNAse $(40 \mathrm{U} / \mathrm{mL})$. Cytochalasin treatment inhibits bacterial killing by inhibiting phagocytosis without blocking PMN degranulation, and DNAse inhibits NET-dependent bacterial killing. The leukocytes were then stimulated with LPS $(100 \mathrm{ng} / \mathrm{mL})$, placed in poly-L-lysine-coated wells of a 24-well tissue culture plate, and incubated at $37^{\circ} \mathrm{C}$ for $1 \mathrm{~h}$ prior to addition of E. coli ( $\left.1 \mathrm{CFU} / 100 \mathrm{PMN}\right)$, followed by continued incubation for $2 \mathrm{~h}$. The PMN were then permeabilized with $0.1 \%$ Triton-X 100 for $10 \mathrm{~min}$ and each well was scraped to free all cells. Serial dilutions were performed and cultures were grown on 5\% sheep blood agar plates (Hardy Diagnostics, Santa Maria, CA). After 24-h incubation, bacterial colonies were counted. We analyzed total and fractional NET-mediated bacterial killing and phagocytosis-mediated bacterial killing.

\section{Statistical analysis}

ANOVA was used to compare parametric data from multiple groups with Neuman-Keuls and Dunnett's C post-hoc testing (Graphpad Software, Inc. San Diego, CA). Survival curves and comparisons between curves were assessed using the Mantel-Cox log-rank test. A value of $p<0.05$ was considered statistically significant when comparing mean and SEM or when comparing survival curves.

\section{Results}

\section{Rosiglitazone improves illness severity scores and survival rate in mice subjected to CLP}

To determine whether there were differences in the effect of rosiglitazone given by different administration routes, animals were treated with rosiglitazone i.v. or i.p. $(0.5 \mathrm{mg} / \mathrm{kg}, 15 \mathrm{~min}$ after CLP) or its vehicle (DMSO). Animals were followed for $144 \mathrm{~h}$. We first observed a decrease in the severity of sepsis in rosiglitazone-treated animals using a clinical score based on changes in appearance, physiology, and behavior as previously described (14). The illness severity score decreased from $6.0 \pm 0.4$ to $3.3 \pm 0.2$ ( $\mathrm{p}<0.0001)$ in septic animals treated i.v. with rosiglitazone (14). A survival rate of $30 \%$ was recorded for the vehicle treated group. Rosiglitazone increased the survival rate to $50 \%$ and $80 \%$ in animals treated by the i.p or i.v. route, respectively. No mortality was observed in sham-operated animals \pm rosiglitazone treatment (Figure 1). We found the i.v. route showed the best results and chose that via for further experiments.

Glitazones have been widely used to treat type 2 diabetes because of their beneficial effects in the control of hyperglycemia (19). Septic mice have a clear trend towards hypoglycemia. Because of that, we determined whether rosiglitazone might interfere with glucose homeostasis in mice challenged by CLP. As expected, blood glucose levels were decreased in CLP animals ( $134 \mathrm{mg} / \mathrm{dL} \pm 12$, sham vs $75 \mathrm{mg} / \mathrm{dL} \pm 7$, CLP). Treatment with rosiglitazone did not further decrease glucose levels in animals subjected to CLP $(75 \mathrm{mg} / \mathrm{dL}$ \pm 7 , CLP + vehicle vs $84 \mathrm{mg} / \mathrm{dL} \pm 3$, CLP + rosiglitazone). 


\section{Rosiglitazone decreases neutrophil accumulation after CLP}

Next, we investigated the effect of rosiglitazone $(0.5 \mathrm{mg} / \mathrm{kg}$, i.v., $15 \mathrm{~min}$ post-surgery) on leukocyte infiltration into the peritoneal cavity after CLP. As expected, CLP animals showed an increase in the numbers of leukocytes (Figure 2A) in the peritoneal cavity $24 \mathrm{~h}$ post CLP mainly due to an influx of neutrophils (Figure 2C). There was no increase in mononuclear cell counts at $24 \mathrm{~h}$ (Figure 2B). Rosiglitazone treatment effectively reduced the number of total leukocytes, as well as the number of neutrophils in the peritoneal cavity when compared to vehicle treated CLP animals (Figure 2A, 2C).

\section{Rosiglitazone has anti-inflammatory effects in septic mice}

To access the anti-inflammatory effect of rosiglitazone treatment in CLP mice we analyzed the levels of IL-6, IL-10 and TNF-a in the peritoneal fluid $24 \mathrm{~h}$ after CLP. These cytokines were chosen because there is evidence that they modify key events in sepsis and other inflammatory conditions. Vehicle-treated septic animals showed increased levels of TNF-a, IL-6 and IL-10 in the peritoneal fluid (Figure 2). On the other hand, rosiglitazone-treated animals showed a marked reduction in TNF-a (Figure 2D), and IL-6 (Figure 2E), levels whereas the anti-inflammatory cytokine IL-10 level was increased when compared to the vehicle treated group (Figure 2F).

\section{Rosiglitazone increases bacterial clearance by NET formation in septic mice}

To investigate whether rosiglitazone treatment had an effect on bacterial clearance that would contribute to the increase in the survival rate shown in Figure 1, we analyzed CFU counts in the peritoneal fluid $24 \mathrm{~h}$ after CLP. As shown in Figure 3A, CFU counts were reduced in the peritoneal fluid recovered from rosiglitazone-treated CLP mice as compared to vehicle treated septic mice, indicating improved bacterial clearance. We next asked whether increased nitric oxide (NO) production, NET formation, and/or intracellular oxidative stress could account for improved bacterial clearance in rosiglitazone treated mice. We observed that CLP animals treated with vehicle had an increase in NO production as compared to sham-operated animals, and that rosiglitazone treatment did not affect NO production (supplemental figure 1).

In additional studies, we measured extracellular DNA in septic animals treated with rosiglitazone via fluorimetry. As shown in Figure 4B, we observed an increase in extracellular DNA content in the CLP group when compared to sham operated animals. CLP animals treated with rosiglitazone showed a further increase in extracellular DNA levels.

We also analyzed the effect of rosiglitazone on the generation of intracellular reactive oxygen species (ROS) in assays where leukocytes were obtained from the blood of CLP mice. We found that in vitro treatment with rosiglitazone increased the production of the antimicrobial ROS hydrogen peroxide by these cells. The results in figure $3 \mathrm{C}$ are consistent with observations indicating that generation of ROS is a key event in the formation of NET (18). A similar effect on ROS generation was obtained with PMA, a well-known ROS inducer and inducer of NET formation (20). PMA and rosiglitazone did not show an additive effect (Figure 3C). In vivo treatment with rosiglitazone was as effective in increasing the production of the antimicrobial ROS hydrogen peroxide by these cells (Figure 3D). 
Our next approach was about the role of rosiglitazone on NET formation induction in vivo in septic animals. Figure 4 nicely shows DNA extracellular release in septic animals. We see an even more pronounced effect of rosiglitazone enhancing DNA extracellular release as a component of NET formation during experimental sepsis (figure 4).

To investigate whether NET formation would play a role in rosiglitazone effect on bacterial clearance and animal survival, we treated septic animals with DNase to dismantle NET and rosiglitazone and analyzed CFU counts in peritoneal lavage at earlier time point ( $3 \mathrm{~h}$ after CLP) and survival curve for 7 days. DNase treatment abolished rosiglitazone decrease in bacterial growth (Figure 5A). DNase treatment also abolished rosiglitazone protective effect on mortality (Figure 5B), showing rosiglitazone effect on bacterial clearance and mortality can be attributed to NET formation during experimental sepsis.

\section{Rosiglitazone increases the bacterial clearance by human PMN incubated with $E$. coli}

Because rosiglitazone decreased CFU counts in mice subjected to CLP, we investigated whether rosiglitazone had an effect on bacterial clearance by human PMN incubated with $E$. coli. We obtained human PMN from healthy individuals and treated them with different concentrations of rosiglitazone $(0.5$ to $50 \mu \mathrm{M})$ for 1 h. E. coli $\left(2 \times 10^{6} \mathrm{CFU} / \mathrm{mL}\right)$ was then added to the culture and after $24 \mathrm{~h}$ the number of CFU was determined. As shown in Figure 6 , the number of CFU was significantly lower in PMN cultures treated with different concentrations of rosiglitazone, with a pronounced effect at the highest concentration (50 $\mu \mathrm{M})$. Rosiglitazone did not have a direct effect on bacterial growth (supplemental figure 2).

\section{Rosiglitazone increases neutrophil extracellular trapping via PPAR $\gamma$ receptor activation}

We next investigated whether PPAR $\gamma$ modulates the formation of NET by human PMN, and if this effect could account for the rosiglitazone-induced increase in bacterial clearance. Purified human PMN were stimulated with LPS $(100 \mathrm{ng} / \mathrm{mL})$ or $E$. coli in the presence or absence of rosiglitazone $(0.5 \mu \mathrm{g} / \mathrm{mL})$ with or without the PPAR $\gamma$ antagonist, GW9662, for 1 h. We detected NET-like structures by confocal microscopy using sytox-orange DNA dye to stain extracellular DNA. As shown in Figure 7, both LPS (Figure 7E) and E. coli (Figure 7I) induced NET formation $1 \mathrm{~h}$ after stimulation. Incubation of neutrophils with rosiglitazone enhanced NET formation after stimulation with LPS (Figure 7F) or E. coli (Figure 7J). Coincubation with rosiglitazone and the PPAR $\gamma$ antagonist, GW9662, inhibited this effect (Figure 7G and Figure 7L). Of note, rosiglitazone (Figure 7C) and GW 9662 showed no independent effects on NET formation on unstimulated cells nor did GW 9662 on LPS or $E$. coli stimulated neutrophils (Figure 7H, 7M, respectively).

We confirmed our results by examining increased extracellular histone $\mathrm{H} 3$ protein content, a surrogate marker for NET formation, in the supernatants of PMN cell cultures stimulated with either LPS $(0.1 \mathrm{ng} / \mathrm{mL}$ ) or E. coli (Figure 8A, 8B, respectively). Again, there was a pronounced rosiglitazone enhancing effect. Here again, incubation with GW 9662 inhibited the effect of rosiglitazone. 


\section{Rosiglitazone-mediated increases in bacterial killing involves NET formation}

Last, we investigated whether rosiglitazone's ability to increase NET formation affects bacterial killing. As shown in Figure 9A, rosiglitazone increased PMN-dependent killing of E. coli. This effect was abolished by GW 9662 . We then assessed phagocytosis-mediated intracellular killing, by pre-incubating LPS-stimulated PMN with DNase to dismantle NET. E. coli was added to the culture and CFU numbers were determined $1 \mathrm{~h}$ later. Under these conditions, incubation of PMN with rosiglitazone did not significantly affect phagocytotic killing (Figure 9B). We next determined the effects of rosiglitazone on NET-mediated extracellular killing, by pre-incubating PMN with cytochalasin B and D to inhibit phagocytotic killing. Rosiglitazone markedly increased NET-mediated extracellular killing (Figure 8C). In agreement with experiments aimed at the detection of NET formation, GW 9662 significantly reduced total and NET-mediated extracellular killing indicating a PPAR $\gamma$ mediated effect on both NET formation and bacterial killing (Figure 9C).

\section{Discussion}

Sepsis is a syndrome caused by dysregulated innate immune responses of the individual to an invading organism. In our study, CLP animals developed manifestations of sepsis including increased illness severity scores consistent with moderate disease, an exacerbated inflammatory response, increased peritoneal bacterial growth, and increased mortality.

Our study aimed to investigate the involvement of the nuclear receptor PPAR $\gamma$ in bacterial clearance in sepsis. The properties of PPAR $\gamma$ agonists have been described in some experimental models of sepsis and septic shock (10). Treatment with PPAR $\gamma$ ligands decreased organ injury associated with hemorrhagic or endotoxic shock or ischemiareperfusion injury in rodent models (21).

TZDs, such as rosiglitazone, are PPAR $\gamma$ agonists that act as insulin-sensitizing drugs by activating transcription of genes responsible for the regulation of glucose metabolism (19). Because glycemic control may have protective effects in sepsis (22), we monitored glucose levels in our model. In contrast to most humans (22), mice develop hypoglycemia after sepsis and this was not affected by rosiglitazone indicating that the protective effect of rosiglitazone is not related to its actions on glucose metabolism.

We showed that intravenous administration of rosiglitazone was the most effective route for administration of the drug in preventing acute mortality due to sepsis. The protective role of rosiglitazone was clinically evident, since it improved the illness severity score used to predict severity of sepsis (14). We have also recently provided evidence that PPAR $\gamma$ agonists modulate leukocyte-endothelial interactions, including rolling and adhesion of leukocytes in brain microvasculature during sepsis (14). Our results are in agreement with those of Zingarelli et al. (21), who found that PPAR $\gamma$ agonists 15d-PGJ2 or ciglitazone increased survival and reduce the inflammatory response in rats subjected to experimental sepsis. Zingarelli et al. (21) also reported that ciglitazone reduced infiltration of leukocytes into the lung, liver, and colon after polymicrobial sepsis in rats. Similarly our findings demonstrated that rosiglitazone reduced the numbers of neutrophils in the peritoneal fluid. Although literature has already described rosiglitazone effects increasing survival during 
sepsis, we are the first to show rosiglitazone post-treatment with a very low dose is equally effective in protecting animals from lethality and decreasing neutrophil counts in the site of infection. These findings are consistent with observations indicating that PPAR ligands inhibit chemotaxis and expression of adhesion molecules $(23,24)$, although we herein describe originally that besides well-known role of PPAR $\gamma$ agonists on leukocyte recruitment modulation, other mechanisms such as NETosis would explain decreased neutrophil numbers at peritoneum.

Excessive production of inflammatory cytokines in sepsis is harmful to the host and may worsen the outcome in experimental and clinical settings (25). TNF-a can reproduce the signs observed during sepsis or endotoxemia. IL-6 is an important biomarker of severity of sepsis, while IL-10 serves as a counterbalance for the intense inflammatory response. Our analysis showed treatment with rosiglitazone decreased the levels of TNF- $a$ and IL-6 in the infected peritoneum. We also showed an increase in IL-10 levels in septic animals treated with rosiglitazone. In agreement, Kim et al. (26) have shown that treatment with pioglitazone or rosiglitazone enhances expression of IL-10 in lung tissue of asthmatic mice and decreasing the illness severity score of these animals. Rosiglitazone-induced increases in IL-10 levels concomitant with decreased IL-6 and TNF-a levels and may contribute, at least in part, to the a better outcome and increased survival of rosiglitazone-treated animals observed in our model. Those findings are consistent to the M1 and M2 paradigm of macrophage activation, where PPAR $\gamma$ promotes the polarization to alternative antiinflammatory M2 macrophages (27).

Besides inflammation, bacterial rapid spread is a distinguished characteristic of sepsis. Neutrophils are first line defense cells that eliminate invading pathogens. We observed that treatment with rosiglitazone significantly modulated neutrophils numbers, cytokine responses, and increased bacterial clearance, which together may account for the protective effect in sepsis. As rosiglitazone did not affect bacterial growth when added directly to bacterial culture, the decrease in CFU observed in our experiments must be related to an effect on the host response. Similarly, a study by Stengenga et al. showed a protective effect of ciglitazone on bacterial growth in a model of pneumonia induced by Streptococcus pneumonia independent of macrophage ability to phagocytize bacteria (28). While the antiinflammatory effects of PPAR $\gamma$ agonists in sepsis have been established (10), the mechanism by which PPAR $\gamma$ activation increases bacterial elimination is still unclear. Indeed, PPARa also seems to modulate the capacity of the host to fight bacteria, since PPARa knockout mice subjected to sepsis are reported to have an increase in bacterial load, that is accompanied by decreased survival (13). Once again, authors do not show the cellular mechanism involved in bacterial clearance.

During inflammation and/or infection, exposure of phagocytic cells to bacterial products, IL-1, TNF- $a$ or IFN- $\gamma$ leads to the production and release of reactive nitrogen species (RNS) and ROS, such as peroxynitrate $\left(\mathrm{ONOO}^{-}\right)$, superoxide $\left(\mathrm{O}^{2-}\right)$ and hydrogen peroxide $\left(\mathrm{H}_{2} \mathrm{O}_{2}\right)$ (29). NO is important in host defense against infection, acting synergistically with ROS to form $\mathrm{ONOO}^{-}$and eliminate bacteria. We observed that cells obtained from the blood of septic animals have increased the intracellular levels of ROS. Rosiglitazone further increased ROS production in these cells, a response that could account in part for its 
enhancement of microbicidal activity. Nonetheless, there was no significant change in NO release in the peritoneum of septic animals treated with rosiglitazone, suggesting the involvement of other killing mechanism.

Neutrophils phagocytize microbes, produce ROS, release antimicrobial factors through degranulation, and form NET as part of their arsenal to fight invading organisms (2). NET is a complex lattice of extracellular fibers, primarily composed of decondensed chromatin, with bound antimicrobial proteins including neutrophil elastase and histones (30). NET kill pathogens efficiently and may in some circumstances limit spread of infection and decrease neutrophil protease-induced damage by locally retaining the proteases and limiting their toxic, proteolytic activity. While the mechanisms governing NET formation remain incompletely characterized, neutrophil elastase migration from primary granules to the nucleus is shown to precede NET formation (18). Myeloperoxidase (MPO), an enzyme present in NET and also a marker of neutrophil activity, migrates to the nucleus, synergizing with elastase to trigger chromatin decondensation, independent of enzymatic activity. Importantly, MPO-deficient patients are unable to form NET and are more susceptible to infections (8), so MPO is actively associated with NET ability to kill bacteria. Furthermore, the addition of $\mathrm{H}_{2} \mathrm{O}_{2}$ in the presence of NET results in greater microbicidal activity, highlighting the synergism between ROS and NET in eliminating pathogens.

We found increased amounts of extracellular DNA in the peritoneal fluid sample from rosiglitazone-treated septic animals, suggesting increased NET formation. It is conceivable that increased intracellular ROS production after rosiglitazone treatment is critical for increased NET formation under the same conditions, a potential proposed mechanism of increased bacterial elimination induced by rosiglitazone. We found extracellular DNA in peritoneal lavage of septic animals and an impressive enhancement effect of rosiglitazone treatment. Images show rosiglitazone may even increases trapping of bacteria.

Literature discusses the role of extracellular histones on toll-like receptor (TLR)2 and TLR4 dependent activation. Circulating extracellular histones are found in plasma of patients in septic shock, potentially contributing to endothelial dysfunction, organ failure, and death in experimental sepsis. Histone can cause inflammation, damage of alveolar epithelial cells, cytokine production, lung gas exchange disturbances and thrombi formation in pulmonary veins. Kalbitz et al. 2015 relate extracellular histones to cardiac dysfunction development, tissue injury and associated lethality in sepsis (31). Although NET components can cause vascular injury under some conditions, NET keeps intact even under blood flow and traps bacteria within the vasculature (4). Deficiency in NET production or the destruction of NET scaffold by DNases have increased susceptibility to infections, aligning evidences in favor of a beneficial role for NET during infections (32). For instance during polymicrobial sepsis DNase treatment reduced NET-mediated bactericidal activity and resulted in augmented bacterial dissemination and tissue damage, showing a beneficial role of NET formation in sepsis (33). Those findings claim NET act as antimicrobial host tool and represent a physical barrier that avoids microbe dissemination, very helpful in early phase of infectious diseases by ensnaring and killing pathogens (32). Our data favor the beneficial role of NET formation during infection. There is no doubt in our model DNA dismantling worsened sepsis prognosis and abolished rosiglitazone protective effect. We highlight the possibility of 
modulating some deleterious effect of extracellular free histones with rosiglitazone, as it showed anti-inflammatory actions.

We found neutrophils stimulated with different concentrations of LPS or incubated with $E$. coli produce NET and that rosiglitazone enhanced that effect directly. NET contains H1, $\mathrm{H} 2 \mathrm{~A}, \mathrm{H} 2 \mathrm{~B}, \mathrm{H} 3$ and $\mathrm{H} 4$ histones besides granule proteins (3). Chromatin decondensation is associated with the conversion of arginine residues to citrulline in histone $\mathrm{H} 3$ in mature neutrophils (34). We found rosiglitazone increased the release of histone $\mathrm{H} 3$ by PMN following stimulation with either LPS or E. coli, confirming our parallel results with live image analysis of NET formation in vitro and in vivo. We showed the effect of rosiglitazone occurred directly in neutrophils and it was mediated by PPAR $\gamma$ activation. Increased ability to eliminate bacteria was related to increased NET formation in either rosiglitazone-treated neutrophils or rosiglitazone-treated septic animals. We analyzed total bacterial killing, phagocytotic intracellular killing, and NET-mediated extracellular killing in vitro. Since the increase in bacterial killing induced by rosiglitazone was dependent on extracellular killing, we surmise that this effect is dependent upon NET formation. Once again, we showed rosiglitazone-induced increased bacterial killing was mediated by the PPAR $\gamma$ receptor activation. The increase in bacterial elimination by rosiglitazone in vitro also occurred in vivo. Rosiglitazone showed a critical beneficial effect on bacterial killing in the peritoneal cavities of infected animals. The disassembling of NET by DNase reverted bacterial clearance favored by rosiglitazone. This is the first demonstration that PPAR $\gamma$ activation increases the formation of NET and improves bacterial elimination in isolated neutrophil and in a model of sepsis.

In summary, we have shown that rosiglitazone favorably modulates the inflammatory response and increases NET-dependent elimination of bacteria in a preclinical model of sepsis. We believe modulation of inflammatory response and NET formation induced by rosiglitazone through PPAR $\gamma$ activation mechanism improved host ability to restrain bacterial spreading increasing survival. These effects may uncover new potential short-term applications for rosiglitazone and other TZD in the treatment of bacterial infections, especially since TZD are well characterized and already approved for clinical use.

Additional pre-clinical data may support new trails to assess TZDs in the management of patients with sepsis.

\section{Supplementary Material}

Refer to Web version on PubMed Central for supplementary material.

\section{Acknowledgements}

This work was funded by Conselho Nacional de Desenvolvimento Científico e Tecnológico (CNPq/Brazil), PAPES-FIOCRUZ, PRONEX (MCT, Brazil), Fundação de Amparo à Pesquisa do Estado do Rio de Janeiro (FAPERJ, Brazil), Coordenação de Aperfeiçoamento de Pessoal de Nível Superior (CAPES, Brazil) and grants from the U.S National Institutes of Health (NIH): 5U54HL 112311 (Andrew S. Weyrich); K08 HD049699 (Christian C. Yost ) and Guy A. Zimmerman (MERIT Award R37HL044525). Dr. Zimmerman is the recipient of a Ciencia Sem Fronteiras (Science Without Borders) Special Visiting Professorship from CNPq. 


\section{Abbreviations}

$\begin{array}{ll}\text { PPAR } \gamma & \text { peroxisome proliferator-activated receptor gamma } \\ \text { CLP } & \text { cecal ligation and puncture } \\ \text { TZD } & \text { thiazolidinediones } \\ \text { NET } & \text { neutrophil extracellular traps }\end{array}$

\section{References}

1. Rittirsch D, Flierl MA, Ward PA. Harmful molecular mechanisms in sepsis. Nat Rev Immunol. 2008; 8(10):776-787. [PubMed: 18802444]

2. Mocsai A. Diverse novel functions of neutrophils in immunity, inflammation, and beyond. J Exp Med. 2013; 210(7):1283-1299. [PubMed: 23825232]

3. Brinkmann V, Reichard U, Goosmann C, Fauler B, Uhlemann Y, Weiss DS, Weinrauch Y, Zychlinsky A. Neutrophil extracellular traps kill bacteria. Science. 2004; 303(5663):1532-1535. [PubMed: 15001782]

4. Clark SR, Ma AC, Tavener SA, McDonald B, Goodarzi Z, Kelly MM, Patel KD, Chakrabarti S, McAvoy E, Sinclair GD, Keys EM, Allen-Vercoe E, Devinney R, Doig CJ, Green FH, Kubes P. Platelet TLR4 activates neutrophil extracellular traps to ensnare bacteria in septic blood. Nat Med. 2007; 13(4):463-469. [PubMed: 17384648]

5. Sumby P, Barbian KD, Gardner DJ, Whitney AR, Welty DM, Long RD, Bailey JR, Parnell MJ, Hoe NP, Adams GG, Deleo FR, Musser JM. Extracellular deoxyribonuclease made by group A Streptococcus assists pathogenesis by enhancing evasion of the innate immune response. Proc Natl Acad Sci U S A. 2005; 102(5):1679-1684. [PubMed: 15668390]

6. Bianchi M, Hakkim A, Brinkmann V, Siler U, Seger RA, Zychlinsky A, Reichenbach J. Restoration of NET formation by gene therapy in CGD controls aspergillosis. Blood. 2009; 114(13):2619-2622. [PubMed: 19541821]

7. Guimaraes-Costa AB, Nascimento MT, Froment GS, Soares RP, Morgado FN, Conceicao-Silva F, Saraiva EM. Leishmania amazonensis promastigotes induce and are killed by neutrophil extracellular traps. Proc Natl Acad Sci U S A. 2009; 106(16):6748-6753. [PubMed: 19346483]

8. Guimaraes-Costa AB, Nascimento MT, Wardini AB, Pinto-da-Silva LH, Saraiva EM. ETosis: A Microbicidal Mechanism beyond Cell Death. J Parasitol Res. 2012; 929743

9. McInturff AM, Cody MJ, Elliott EA, Glenn JW, Rowley JW, Rondina MT, Yost CC. Mammalian target of rapamycin regulates neutrophil extracellular trap formation via induction of hypoxiainducible factor 1 alpha. Blood. 2012; 120(15):3118-3125. [PubMed: 22919032]

10. Zingarelli B, Cook JA. Peroxisome proliferator-activated receptor-gamma is a new therapeutic target in sepsis and inflammation. Shock. 2005; 23(5):393-399. [PubMed: 15834303]

11. Zapolska-Downar D, Naruszewicz M. Propionate reduces the cytokine-induced VCAM-1 and ICAM-1 expression by inhibiting nuclear factor-kappa B (NF-kappaB) activation. J Physiol Pharmacol. 2009; 60(2):123-131. [PubMed: 19617655]

12. Kaplan JM, Cook JA, Hake PW, O'Connor M, Burroughs TJ, Zingarelli B. 15-Deoxy-delta(12,14)prostaglandin $\mathrm{J}(2)$ (15D-PGJ(2)), a peroxisome proliferator activated receptor gamma ligand, reduces tissue leukosequestration and mortality in endotoxic shock. Shock. 2005; 24(1):59-65. [PubMed: 15988322]

13. Standage SW, Caldwell CC, Zingarelli B, Wong HR. Reduced peroxisome proliferator-activated receptor alpha expression is associated with decreased survival and increased tissue bacterial load in sepsis. Shock. 2012; 37(2):164-169. [PubMed: 22089192]

14. Araujo CV, Estato V, Tibirica E, Bozza PT, Castro-Faria-Neto HC, Silva AR. PPAR gamma activation protects the brain against microvascular dysfunction in sepsis. Microvasc Res. 2012; 84(2):218-221. [PubMed: 22659381] 
15. Baker CC, Chaudry IH, Gaines HO, Baue AE. Cecal ligation and puncture. Evaluation of factors affecting mortality rate after sepsis in a murine cecal ligation and puncture model. Surgery. 1983; 94(2):331-335. [PubMed: 6879447]

16. Hubbard WJ, Choudhry M, Schwacha MG, Kerby JD, Rue LW 3rd, Bland KI, Chaudry IH. Cecal ligation and puncture. Shock. 2005; (24 Suppl 1):52-57. [PubMed: 16374373]

17. Reis PA, Estato V, da Silva TI, d'Avila JC, Siqueira LD, Assis EF, Bozza PT, Bozza FA, Tibirica EV, Zimmerman GA, Castro-Faria-Neto HC. Statins decrease neuroinflammation and prevent cognitive impairment after cerebral malaria. PLoS Pathog. 2012; 8(12):e1003099. [PubMed: 23300448]

18. Yost CC, Cody MJ, Harris ES, Thornton NL, McInturff AM, Martinez ML, Chandler NB, Rodesch CK, Albertine KH, Petti CA, Weyrich AS, Zimmerman GA. Impaired neutrophil extracellular trap (NET) formation: a novel innate immune deficiency of human neonates. Blood. 2009; 113(25): 6419-6427. [PubMed: 19221037]

19. Yki-Jarvinen H. Thiazolidinediones. N Engl J Med. 2004; 351(11):1106-1118. [PubMed: 15356308]

20. Fuchs TA, Abed U, Goosmann C, Hurwitz R, Schulze I, Wahn V, Weinrauch Y, Brinkmann V, Zychlinsky A. Novel cell death program leads to neutrophil extracellular traps. J Cell Biol. 2007; 176(2):231-241. [PubMed: 17210947]

21. Zingarelli B, Sheehan M, Hake PW, O'Connor M, Denenberg A, Cook JA. Peroxisome proliferator activator receptor-gamma ligands, 15-deoxy-Delta(12,14)-prostaglandin $\mathrm{J} 2$ and ciglitazone, reduce systemic inflammation in polymicrobial sepsis by modulation of signal transduction pathways. $\mathbf{J}$ Immunol. 2003; 171(12):6827-6837. [PubMed: 14662889]

22. de Jonghe B, Lacherade JC, Sharshar T, Outin H. Intensive care unit-acquired weakness: risk factors and prevention. Crit Care Med. 2009; 37(10 Suppl):S309-S315. [PubMed: 20046115]

23. Reddy RC, Standiford TJ. Effects of sepsis on neutrophil chemotaxis. Curr Opin Hematol. 2010; 17(1):18-24. [PubMed: 19864946]

24. Reddy RC, Narala VR, Keshamouni VG, Milam JE, Newstead MW, Standiford TJ. Sepsis-induced inhibition of neutrophil chemotaxis is mediated by activation of peroxisome proliferator-activated receptor-\{gamma\}. Blood. 2008; 112(10):4250-4258. [PubMed: 18535203]

25. Matsuda A, Jacob A, Wu R, Aziz M, Yang WL, Matsutani T, Suzuki H, Furukawa K, Uchida E, Wang P. Novel therapeutic targets for sepsis: regulation of exaggerated inflammatory responses. J Nippon Med Sch. 2012; 79(1):4-18. [PubMed: 22398786]

26. Kim SR, Lee KS, Park HS, Park SJ, Min KH, Jin SM, Lee YC. Involvement of IL-10 in peroxisome proliferator-activated receptor gamma-mediated anti-inflammatory response in asthma. Mol Pharmacol. 2005; 68(6):1568-1575. [PubMed: 16150927]

27. Martinez FO, Gordon S. The M1 and M2 paradigm of macrophage activation: time for reassessment. F1000Prime Rep. 2014; 6:13. [PubMed: 24669294]

28. Stegenga ME, Florquin S, de Vos AF, van der Poll T. The thiazolidinedione ciglitazone reduces bacterial outgrowth and early inflammation during Streptococcus pneumoniae pneumonia in mice. Crit Care Med. 2009; 37(2):614-618. [PubMed: 19114898]

29. Kirkeboen KA, Strand OA. [Nitric oxide--an important mediator in sepsis?]. Tidsskr Nor Laegeforen. 1999; 119(27):4061-4065. [PubMed: 10613098]

30. Tillack K, Breiden P, Martin R, Sospedra M. T lymphocyte priming by neutrophil extracellular traps links innate and adaptive immune responses. J Immunol. 2012; 188(7):3150-3159. [PubMed: 22351936]

31. Kalbitz M, Grailer JJ, Fattahi F, Jajou L, Herron TJ, Campbell KF, Zetoune FS, Bosmann M, Sarma JV, Huber-Lang M, Gebhard F, Loaiza R, Valdivia HH, Jalife J, Russell MW, Ward PA. Role of extracellular histones in the cardiomyopathy of sepsis. FASEB J. 2015; 29(5):2185-2193. [PubMed: 25681459]

32. Camicia G, Pozner R, de Larranaga G. Neutrophil extracellular traps in sepsis. Shock. 2014; 42(4): 286-294. [PubMed: 25004062]

33. Meng W, Paunel-Gorgulu A, Flohe S, Hoffmann A, Witte I, Mackenzie C, Baldus SE, Windolf J, Logters TT. Depletion of neutrophil extracellular traps in vivo results in hypersusceptibility to polymicrobial sepsis in mice. Crit Care. 2012; 16(4):R137. [PubMed: 22835277] 
34. Wang D, Lippard SJ. Cisplatin-induced post-translational modification of histones H3 and H4. J Biol Chem. 2004; 279(20):20622-20625. [PubMed: 15010460] 


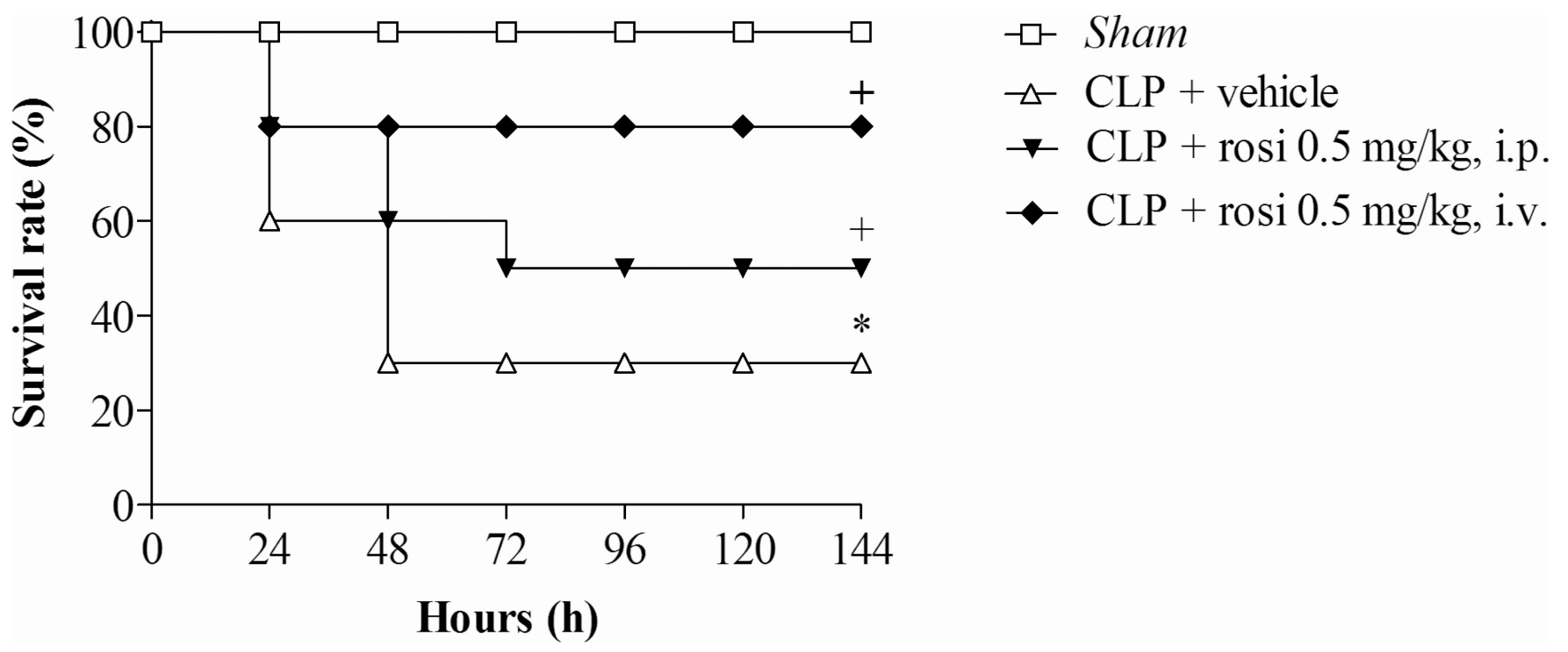

Figure 1. Rosiglitazone protects mice from mortality after CLP Swiss

Mice were anaesthetized, submitted to CLP and subsequently treated with rosiglitazone (0.5 $\mathrm{mg} / \mathrm{kg}$ i.p. or i.v) or vehicle $15 \mathrm{~min}$ after CLP. Sham operated animals were included as controls. The survival rate was monitored for 7 days in animals randomized to vehicle, rosiglitazone $0.5 \mathrm{mg} / \mathrm{kg}$ i.p., or rosiglitazone $0.5 \mathrm{mg} / \mathrm{kg}$ i.v. treatment. The experiment was performed 4 independent times, with 10 animals for each group. $*$ denotes $\mathrm{p}<0.05$ when compared to sham animals. + denotes $p<0.05$ when compared to septic animals. 

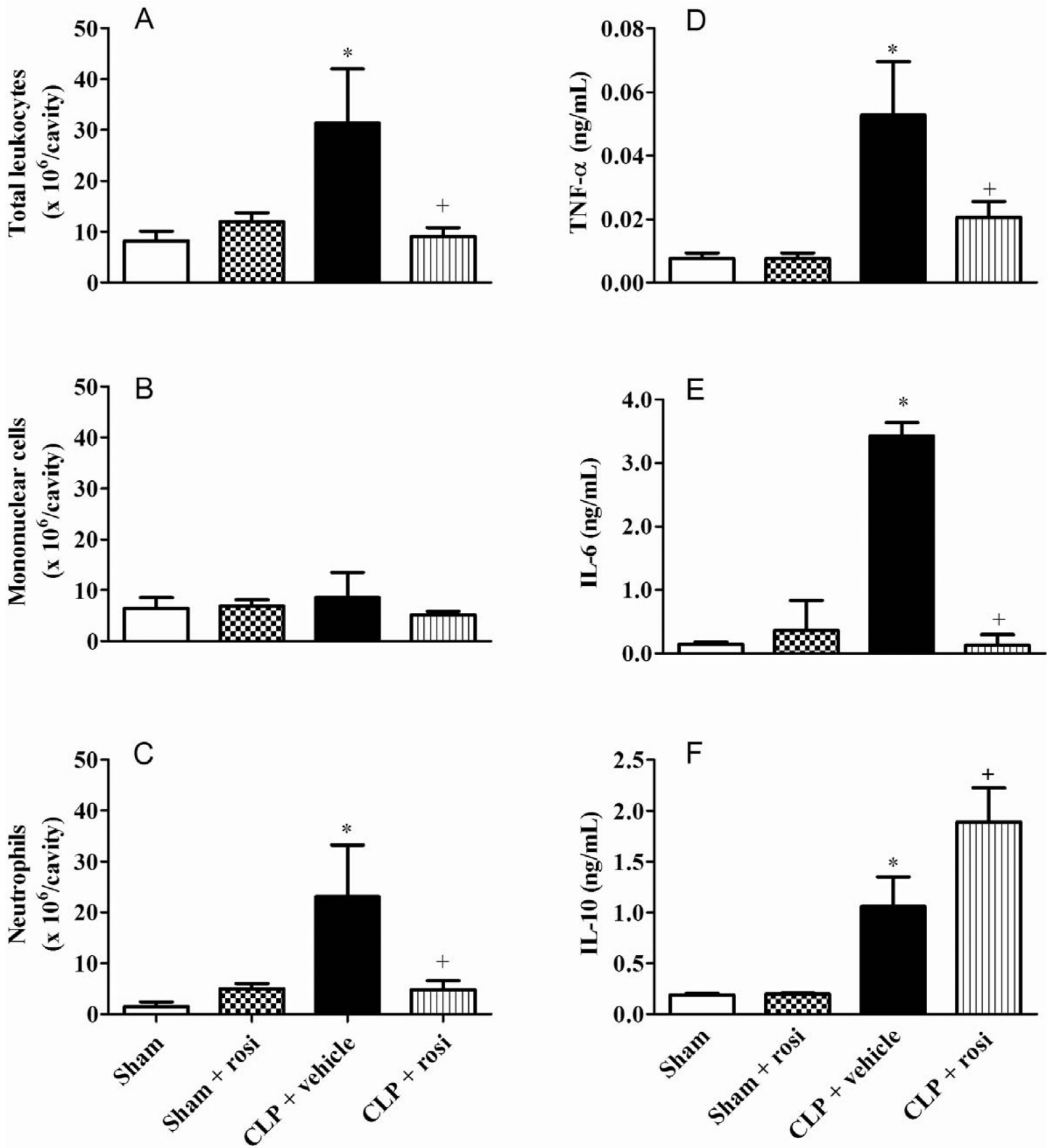

Figure 2. Rosiglitazone inhibits neutrophil accumulation the peritoneal fluid of mice subjected to CLP

Swiss mice were submitted to CLP and 15 min later were treated with rosiglitazone $(0.5$ $\mathrm{mg} / \mathrm{kg}$, i.v.) or vehicle. Twenty-four hours later the mice were euthanized, and the peritoneal fluid was collected for total leukocytes (A), mononuclear cells (B), and neutrophils (C) counts and TNFa (D), IL-6 (E) and IL-10 (F) measurement by ELISA. Each bar represents the mean \pm SEM from at least 6 animals. The experiment was performed 3 independent times. * denotes $\mathrm{p}<0.05$ when compared with sham groups and + denotes $\mathrm{p}<0.05$ when compared with CLP + vehicle. 

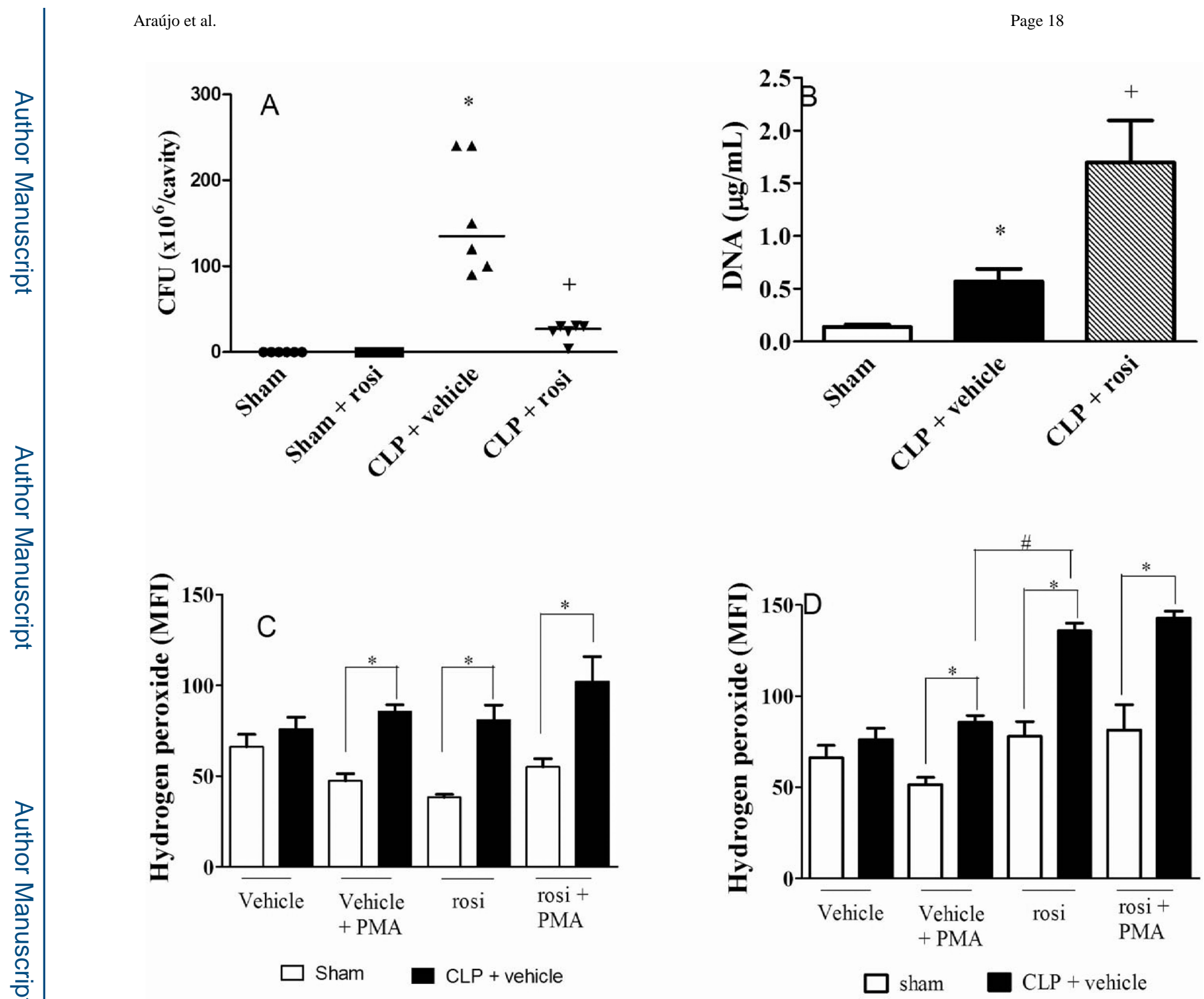

Figure 3. Rosiglitazone increases bacterial clearance and ROS production during sepsis Swiss mice were submitted to CLP and treated or not with rosiglitazone $(0.5 \mathrm{mg} / \mathrm{kg}$, i.v. $)$ or vehicle 15 min after surgery. Peritoneal lavage fluid was collected 3 or $24 \mathrm{~h}$ later. (A) CFU analysis of peritoneal lavage obtained from rosiglitazone-treated septic animals $24 \mathrm{~h}$ after CLP; (B) DNA quantification of peritoneal lavage obtained from rosiglitazone-treated septic animals. (C) In vitro effect of rosiglitazone on the oxidative burst in cells obtained from the blood of septic mice. Blood samples were collected $4 \mathrm{~h}$ after CLP. Total leukocytes were incubated for $1 \mathrm{~h}$ with rosiglitazone (Rosi; $5 \mu \mathrm{M}, 37^{\circ} \mathrm{C}$ ) and then stimulated with PMA in the presence of catalase and DHR for fluorescence measurement of rhodamine 123 (represented as mean of fluorescence intensity - MFI) in FACS. (D) Effect of rosiglitazone in vivo treatment on the oxidative burst in cells obtained from the blood of septic mice. Animals were submitted to CLP and treated with rosiglitazone (Rosi; $0.5 \mathrm{mg} / \mathrm{kg}$ i.v.). Blood 
samples were collected $4 \mathrm{~h}$ after CLP. Total leukocytes were stimulated with PMA in the presence of catalase and DHR for fluorescence measurement of rhodamine 123 (represented as mean of fluorescence intensity - MFI) in FACS. 

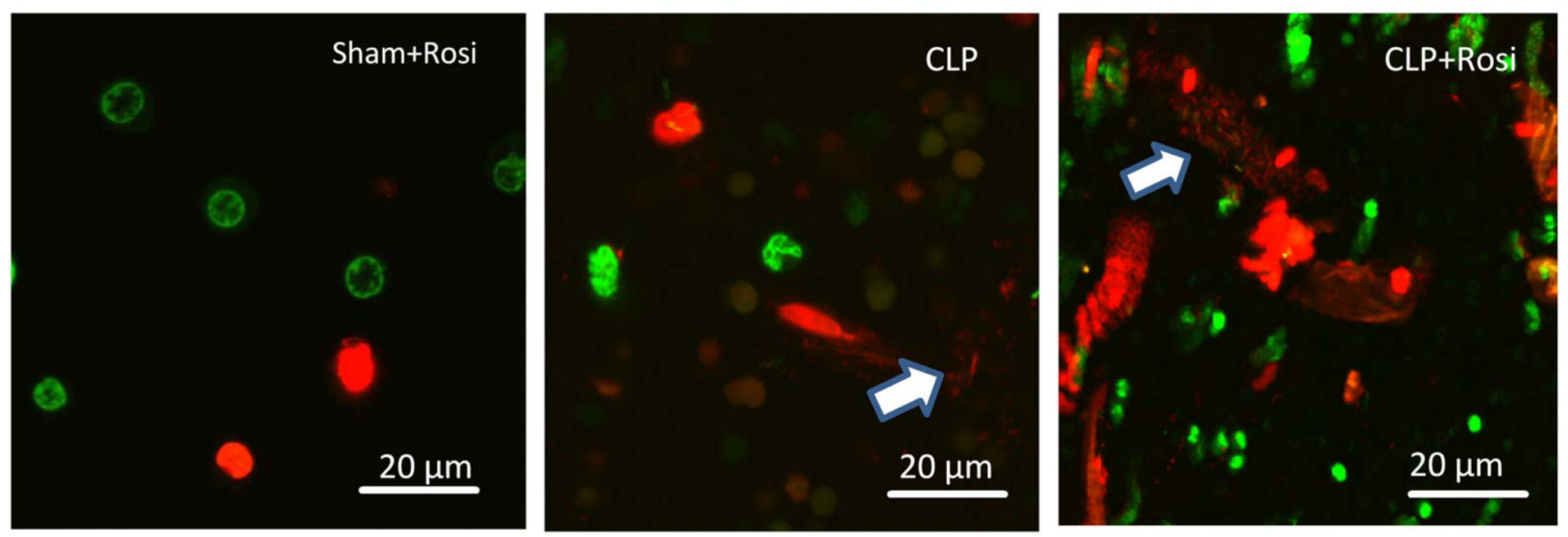

Figure 4. Rosiglitazone treatment increased NET formation in septic mice NET formation was detected by live cell imaging with confocal microscopy using 2 DNA dyes, one cell impermeable (Sytox Orange, which stains extracellular DNA red and dead bacteria in these images) and the other cell permeable (Syto Green, which identifies nuclear DNA). Experiments were performed on poly-l-lysine-coated glass coverslips. NET formation was examined by scanning electron microscopy 3 hours after CLP, 60x objective. The images are representative of 1 experiment from 3 different animals from each subjective group (sham+rosi, CLP, CLP+Rosi). The arrows show dead bacteria trapped by NET. 


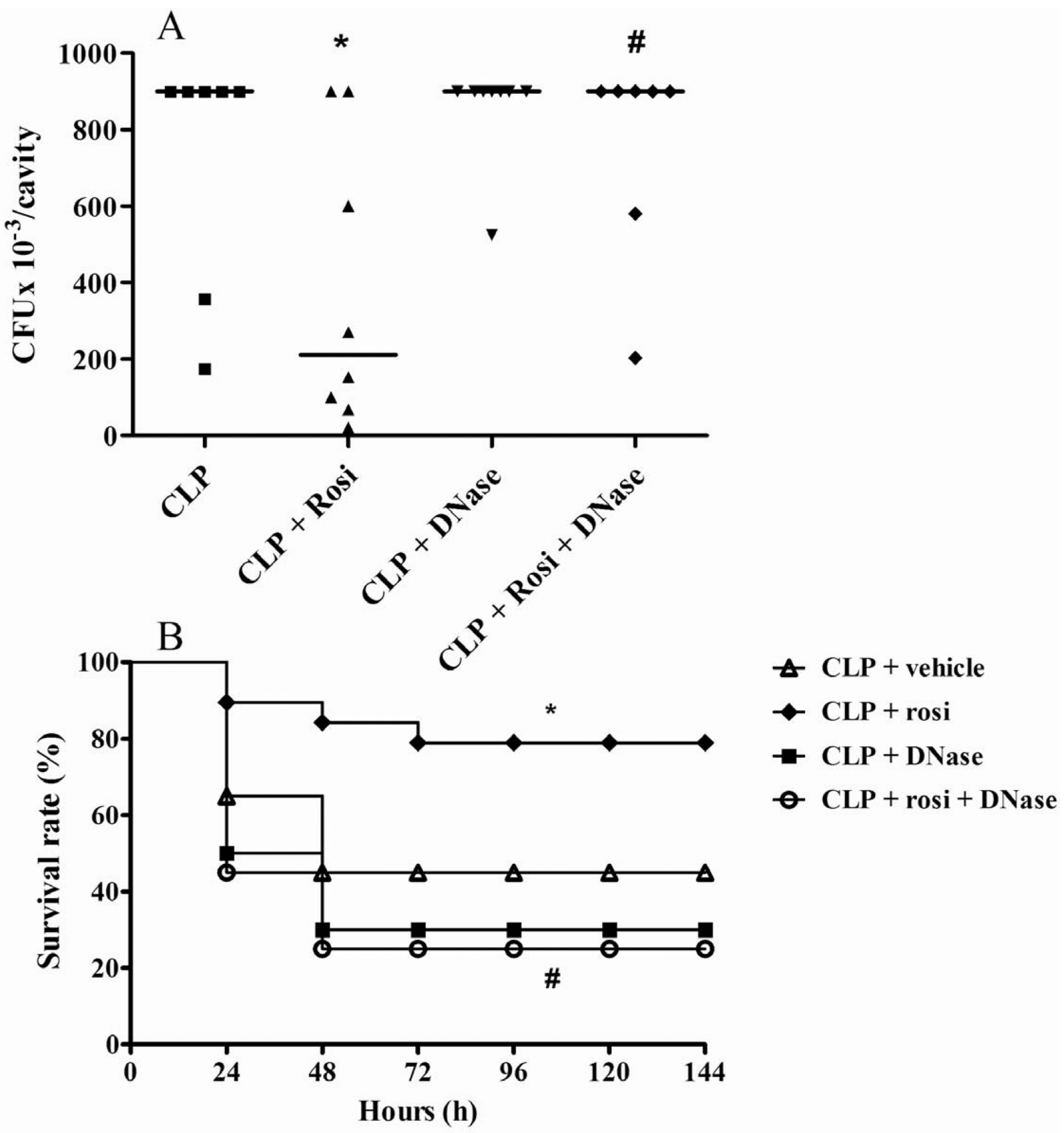

Figure 5.

DNase treatment abolishes rosiglitazone-induced bacterial killing and increase in survival in septic animals. Swiss Mice were anaesthetized, submitted to CLP and treated with rosiglitazone $(0.5 \mathrm{mg} / \mathrm{kg}$ i.v) or vehicle $15 \mathrm{~min}$ after CLP. Some animals also received DNase treatment $1 \mathrm{~h}$ after CLP ( $5 \mathrm{mg} / \mathrm{kg}$, i.v.). (A) CFU analysis ( $3 \mathrm{~h}$ after CLP) of peritoneal lavage obtained from septic animals treated with rosiglitazone and DNase. CFU counts are expressed as individual values and median columns are the mean \pm SEM from at least 6 animals per group. The experiment was performed 3 independent times. Sham 
operated animals were included as controls in survival experiment. The survival rate was monitored for 7 days in animals. The experiment was performed with 10 animals for each group. In (A) * denotes $\mathrm{p}<0.05$ when comparing to CLP, while \# denotes $\mathrm{p}<0.05$ when comparing CLP + Rosi vs. CLP + Rosi + DNase. In (B) * denotes p $<0.05$ when compared to sham animals. + denotes $p<0.05$ when compared to septic animals, while \# denotes $p<$ 0.05 when comparing CLP + Rosi vs. CLP + Rosi + DNase. 


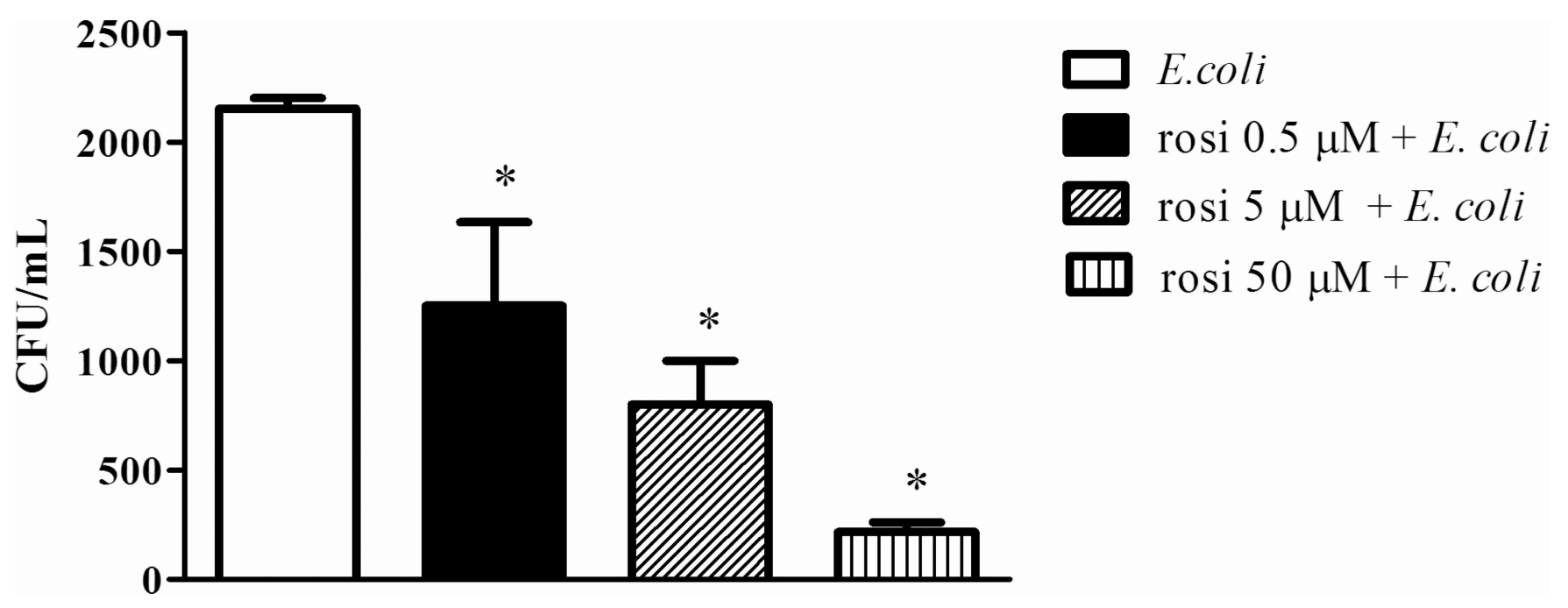

Figure 6. Rosiglitazone increases bacterial clearance by PMN in vitro Human PMN were purified and incubated with E. coli in the presence or absence of rosiglitazone or vehicle (DMSO). The data represent 3 different experiments with different donors. Each bar represents the mean \pm SEM. $*$ denotes $\mathrm{p}<0.05$ compared to E. coli stimulated PMN. 


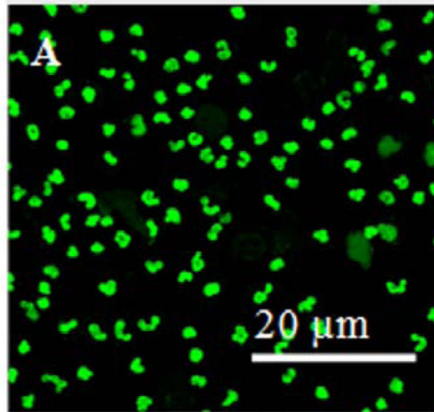

DMSO

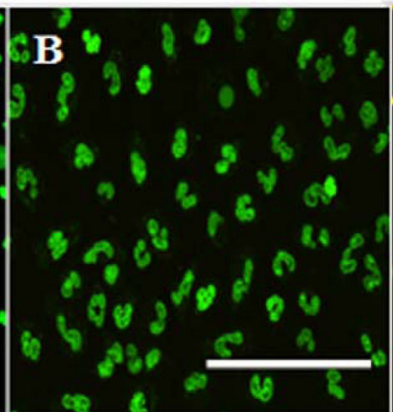

Ethanol

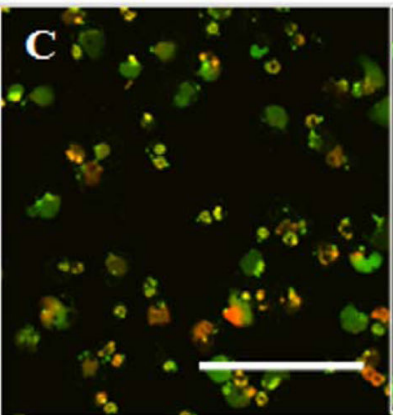

rosiglitazone

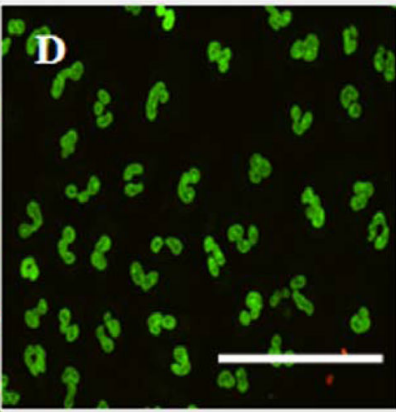

GW 9662

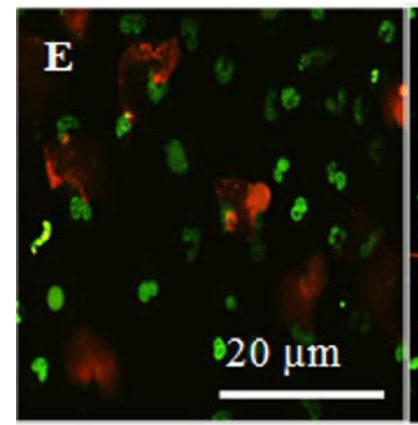

LPS + DMSO

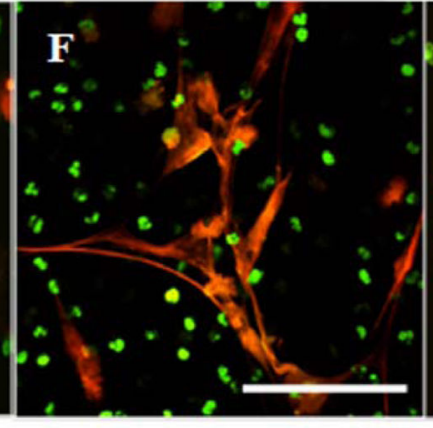

LPS + rosiglitazone

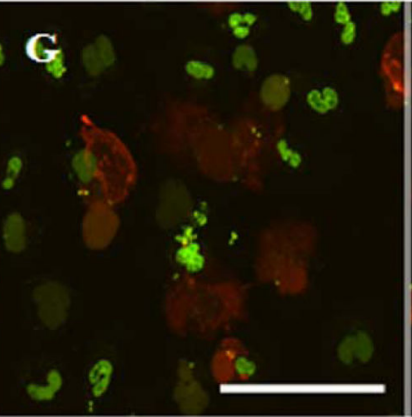

LPS + rosiglitazone

+ GW9662

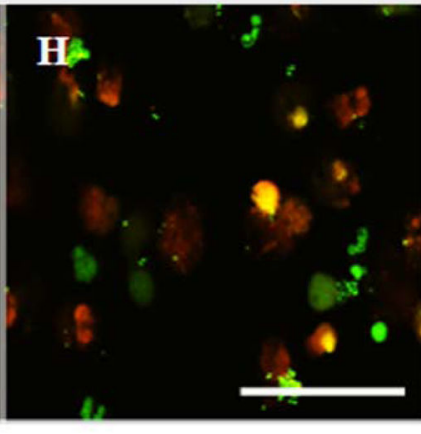

LPS + GW9662

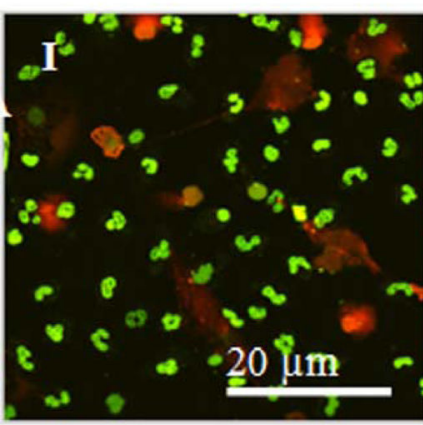

E.coli + DMSO

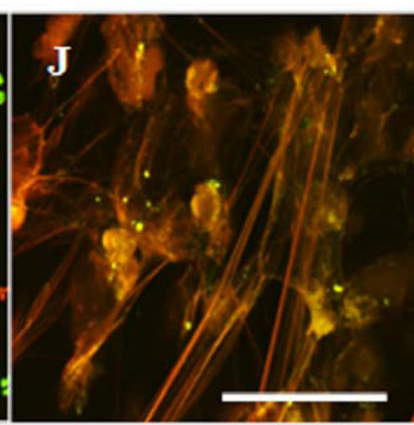

E. coli + rosiglitazone

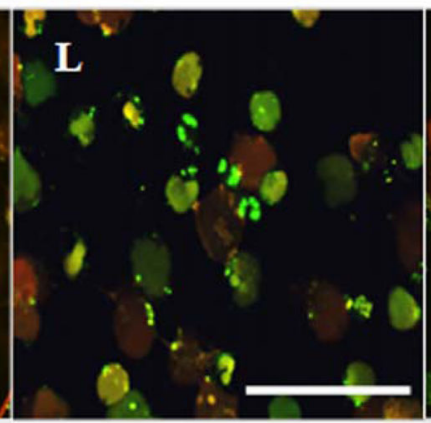

E. coli + rosiglitazone + GW9662

Figure 7. PPAR $\gamma$ activation directly enhances DNA extracellular release induced by LPS or $E$. coli

Human PMN were purified and incubated with LPS $(0.1 \mathrm{ng} / \mathrm{mL})$ or E. coli $\left(2 \times 10^{6}\right.$

$\mathrm{CFU} / \mathrm{mL})$ in the presence and absence of rosiglitazone $(0.5 \mu \mathrm{M}), \mathrm{GW} 9662(0.5 \mu \mathrm{M})$, or vehicle (DMSO or ethanol was added to the suspension). The cells were then placed on slides pre-coated with poly-L-lysine and incubated for $1 \mathrm{~h}$. Extracellular DNA was stained with Sytox-orange and the nuclear DNA with Syto-green. Conditions represented in images: (A) DMSO; (B) ethanol; (C) rosiglitazone; (D) GW9662, (E) LPS + DMSO; (F) LPS + 
rosiglitazone; (G) LPS + rosiglitazone + GW 9662; (H) LPS + GW 9662; (I) E. coli + DMSO; (J) E. coli + rosiglitazone; (L) E. coli + rosiglitazone + GW 9662; (M) E. coli + GW 9662. Three separate experiments were performed with PMN from different donors. The images were captured using confocal microscopy and a 60x objective. 

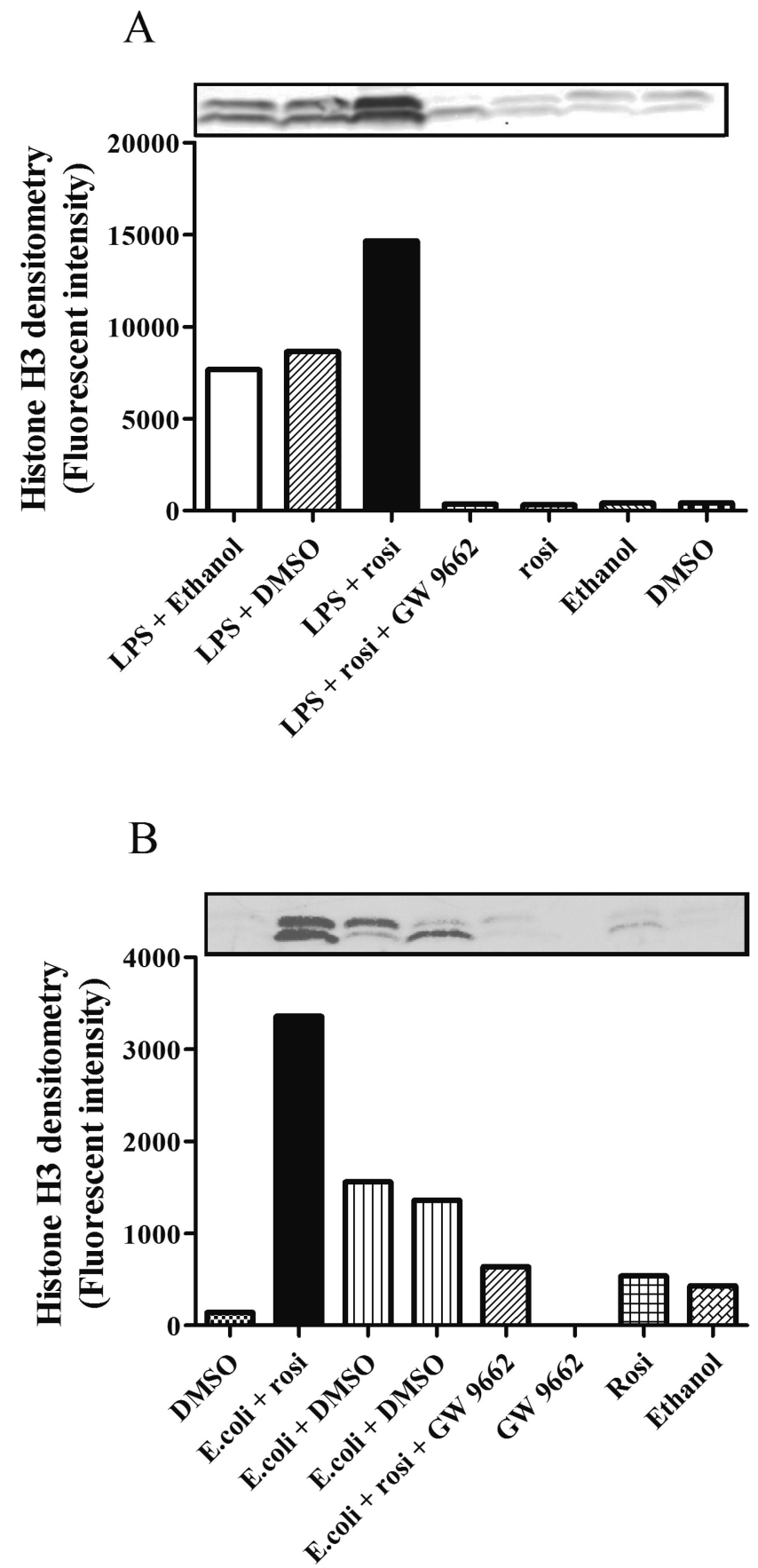

Figure 8. Rosiglitazone enhances histone $\mathrm{H3}$ release by $\mathrm{PMN}$ in vitro

Human PMN were purified and (A) LPS $(0.1 \mathrm{ng} / \mathrm{mL})$ or (B) E. coli was added to the cells in the presence of rosiglitazone (Rosi; $0.5 \mu \mathrm{M})$ and/or GW9662 (0.5 $\mu \mathrm{M})$. DMSO or ethanol were used as vehicle controls. The experiments were performed on poly-L-lysine glass coverslips. DNase (2.5 U/mL) was added following LPS stimulation (60 min) to dismantle extracellular NET and the supernatant was collected for histone H3 quantitation by western blotting. Data were repeated twice with PMNs from different donors. 

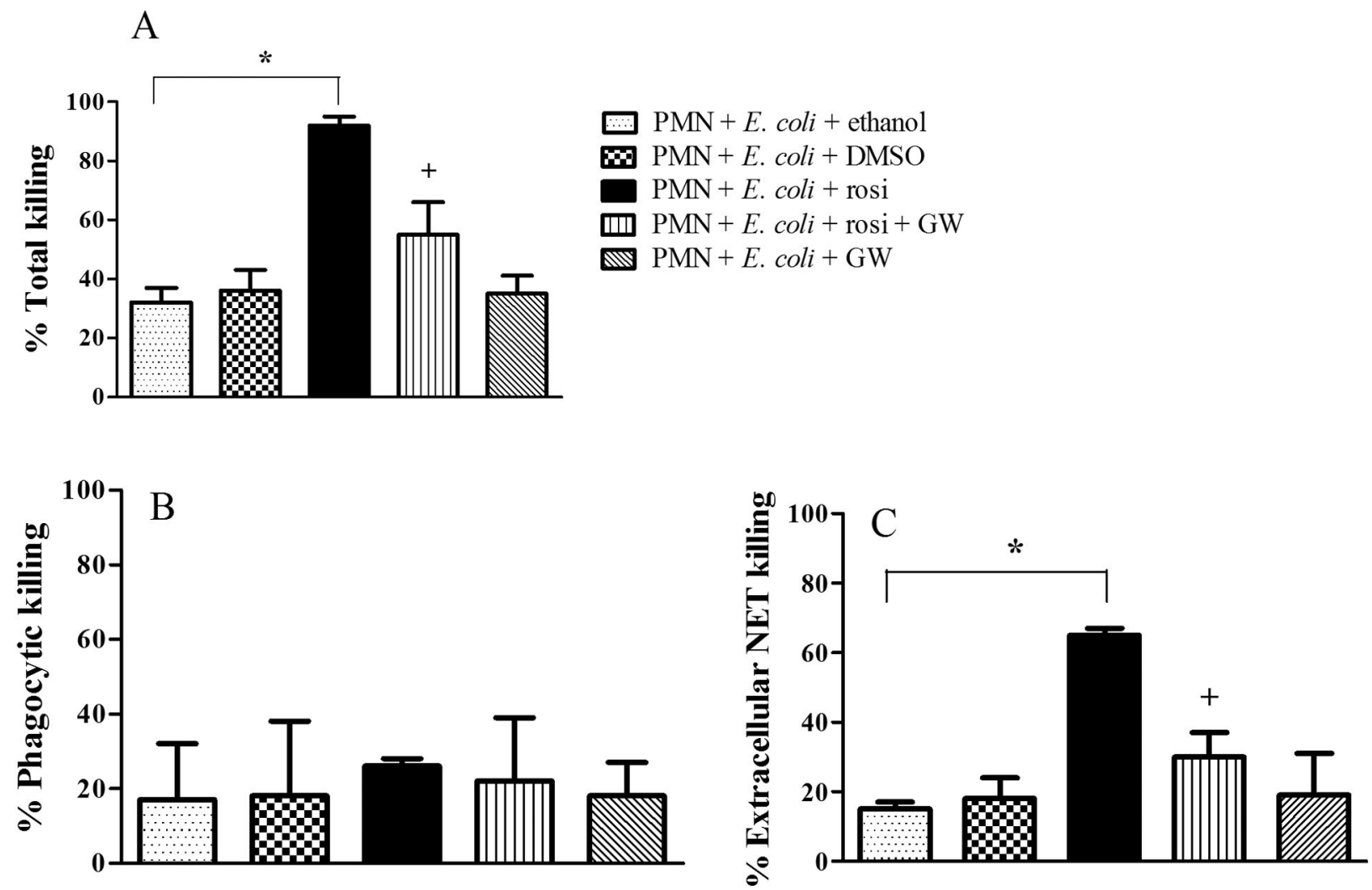

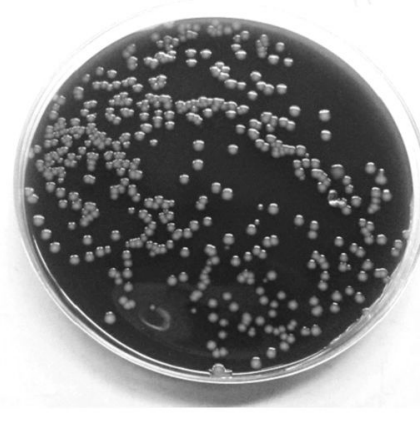

$\mathrm{PMN}+$ E. coli

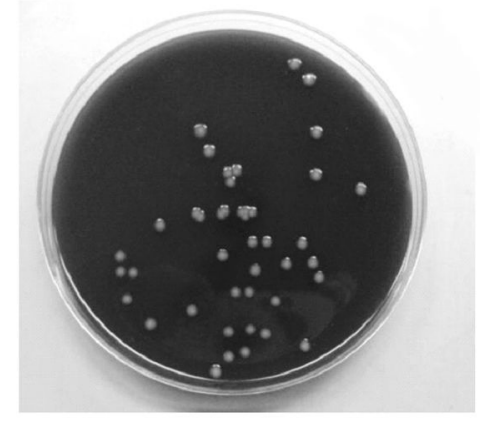

$\mathrm{PMN}+$ cytochalasin + E. coli + rosi

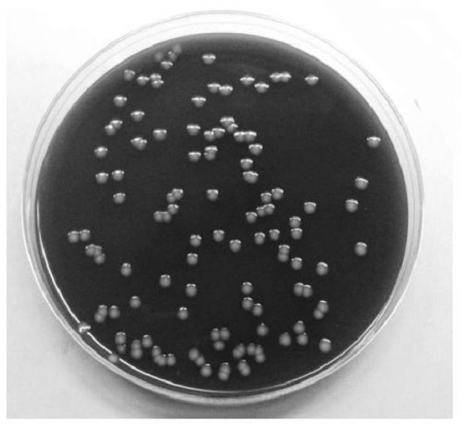

$\mathrm{PMN}+$ cytochalasin + E. coli + rosi $+\mathrm{GW}$

Figure 9. Rosiglitazone increases NET-mediated extracellular bacterial killing

(A) Total killing of E. coli mediated by phagocytosis and NET formation in PMN stimulated with LPS $(0.1 \mathrm{ng} / \mathrm{mL}) \pm$ rosiglitazone (Rosi; $0.5 \mu \mathrm{M})$ and/or GW $9662(\mathrm{GW} ; 0.5 \mu \mathrm{M})$ was determined. (B) Phagocytotic killing of E. coli in PMN stimulated with LPS $(0.1 \mathrm{ng} / \mathrm{mL}) \pm$ rosiglitazone (Rosi; $0.5 \mu \mathrm{M}$ ) and/or GW 9662 (GW; $0.5 \mu \mathrm{M}$ ) was determined. (C) NETmediated killing of $E$. coli in PMN stimulated with LPS $(0.1 \mathrm{ng} / \mathrm{mL}) \pm$ rosiglitazone (Rosi; $0.5 \mu \mathrm{M})$ and/or GW $9662(\mathrm{GW} ; 0.5 \mu \mathrm{M})$ was examined in parallel. Data are represented as the mean \pm SEM of 3 different experiments from different PMN donors. * denotes $\mathrm{p}<0.05$ 
compared to $E$. coli. + denotes p $<0.05$ compared to $E$. coli + Rosi. The agar plate images were analyzed in 3 independent studies, showing images of CFU from PMN $+E$ coli, PMN + cytochalasin $+E$. coli + rosiglitazone, $\mathrm{PMN}+$ cytochalasin $+E$. coli + rosiglitazone + GW. 